\title{
地震加速度記録の積分による変位波形の 計算手法
}

\author{
本山 紘希 1 - 室野 剛隆 2 \\ 1正会員（公財）鉄道総合技術研究所 構造物技術研究部（广 185-8540東京都国分寺市光町2-8-38） \\ E-mail:motoyama@rtri.or.jp \\ 2正会員（公財）鉄道総合技術研究所 構造物技術研究部（ $185-8540$ 東京都国分寺市光町2-8-38） \\ E-mail: murono@rtri.or.jp
}

\begin{abstract}
地震による各地の変位波形やそこから得られる残留変位は, 地震の特徴を理解する上で重要な情報であ る．各地の地震加速度記録を用いて変位波形を計算する際は時間積分を行うことが一般的であるが，多く の場合，変位波形にトレンド成分が発生し，正確な值を把握することは難しい。これは，観測記録の長周 期成分が地震計の傾きや観測ノイズなどに影響されやすいためである. トレンド成分を取り除くために長 周期成分をカットすることもあるが，長周期成分は変位波形への影響も大きいため，本来，慎重な扱いが 必要である。そこで，観測記録から地震計の傾きという物理的に意味のある成分を特定・除去し，得られ た波形に対して，依然観測ノイズの影響分が大きい場合のみ，影響を受ける周波数領域をカットする，と いう手法を提案した。また，フーリエ変換による波形の歪みを抑えるため，因果律を拘束条件とした周波 数領域での積分手法を合わせて用いている，最後に，これらの手法を，岩手・宮城内陸地震(2008)に使用 し，適用性を確認した。
\end{abstract}

Key Words : residual displacement, integration method in frequency domain, tilt motion of sensors

\section{1. はじめに}

近年では，高密度地震観測網の整備により，膨大な強 震記録が得られるようになった。 これらの強震記録を処 理し，変位波形を得ることは，地動の動きを知る上で有 用である。また，鉄道を例に取れば，列車の走行性を考 える際に，地表面および構造物上の変位を推定すること は極めて重要であり, 正確な変位波形の推定方法は様々 な活用が期待される.

一般的な変位波形の計算方法は，加速度波形として得 られている観測記録を時間軸上で積分するというもので ある、しかし，地震動においては，変位波形に寄与の大 きい長周期成分ほど振幅が小さくなり，ノイズの影響を 受けやすくなることから，変位波形を計算してみると， トレンド成分が発生し，正確な変位の推定が困難な場合 が多い.

また，ノイズではないが，一般的な振子型の強震計で は，強震計を設置する地盤の傾斜の影響を受けるため， 加速度波形の基線が地震動を受ける中でずれることがあ る. 基線のずれた加速度波形をそのまま積分すると上記 と同様にトレンド成分が生じるため，正確な変位波形の
推定には傾斜成分の特定および除去が必要となる.

これらの変位波形に生じるトレンドを除去する一般的 な手法として，高域通過フィルターを使用する方法があ る.しかし，近年のデジタル強震計では長周期成分にお いても精度の改善がなされており, 除去す心゙きノイズの 影響は限定的であると考えられ，従来通りの手法で長周 期の振幅を一律に落とす手法は観測記録を歪めている可 能性がある。

高域通過フィルターの適用を行わず，時刻歴加速度波 形を処理することで, 変位波形を計算する手法も提案さ れている例えば1)，これらの手法は有用な手法であり，実 際の地震観測記録に対する適用性も高いことが確認され ているが，観測波形からノイズを除去して正確な地震動 を取り出すということを考えると，何らかのフィルター 処理を前提とした波形の処理方法についても活用の可能 性が期待できる.

そこで本研究では，長周期成分を一律に落とすことを せずにトレンド成分を除去するため，物理的に意味を持 つ傾斜成分の特定・除去を行い，その上でノイズの影響 を受ける周波数領域のみをカットするという手法を提案 する．また，低周波数領域をカットする際に必要なフー 
リエ変換と, 周波数領域での振幅のカットが波形を歪め てしまうことを避けるため, 因果律を拘束条件とし，フ ーリエ変換の実数部のみを用いた変位波形の計算手法も 合わせて用いている.

\section{2. トレンド成分の要因とトレンドの除去}

\section{(1) センサの傾斜成分}

最も一般的な強震計は振り子を用いた加速度計であ る.一般的に，地震計は並進運動の夕に感度を持つと仮 定されるが，振り子型の地震計は地面の傾斜（回転）運 動に対しても感度を持つ. Graizerは回転や傾斜を含む振 り子の完全な運動方程式を導いている2). さらに, 数值 解析による感度解析から各項の影響を検証し ${ }^{3)}$, 運動方 程式の近似式を導いた。

$$
\begin{aligned}
& \ddot{y}_{1}+2 \omega_{1} D_{1} \dot{y}_{1}+\omega_{1}^{2} y_{1}=-\ddot{x}_{1}+g \varphi_{2} \\
& \ddot{y}_{2}+2 \omega_{2} D_{2} \dot{y}_{2}+\omega_{2}^{2} y_{2}=-\ddot{x}_{2}+g \varphi_{1} \\
& \ddot{y}_{3}+2 \omega_{3} D_{3} \dot{y}_{3}+\omega_{3}^{2} y_{3}=-\ddot{x}_{3}
\end{aligned}
$$

ここに, $y_{i}$ は地震計の応答記録 $(i=1,2$ : 水平2方向, 3 : 鉛直方向 $), \omega_{i}$ と $D_{i}$ は変換器の固有振動数と臨界減 衰比, $g$ は重力加速度, $\ddot{x}_{i}$ は $i$ 方向の地動加速度, $\varphi_{i}$ は $x_{i}$ 軸回りの地動の回転角である．つまり，水平方向の 地震記録は地動の水平加速度と地震計の傾斜の両者から 影響を受ける.

本論文では，地震計の傾斜は地震動を受ける中で，あ る瞬間に一度だけ起こると仮定する. 加えて，傾斜成分 は地震動に対してステップ状関数として表現できること とした.これにより，観測加速度波形は「真の地震動」 に傾斜成分を表す「ステップ状関数」を足し合わせるこ とで表現できる（図-1）。この仮定の元，観測波形の中 に混入しているステップ状関数を特定する方法を提案す る.ここでは，観測記録のフーリエスペクトルからステ ップ状関数を特定する手法を提案している.

フーリエスペクトルを用いた混入ステップ状関数の特 定手法について説明する. データ数 $N$, 継続時間が $T_{\mathrm{A}}$ の 観測波形（地震動十ステップ状関数）に対してフーリエ 変換（FFT）を行うとする.この際，FFTに用いるデー 夕数を2の累乗個とするため, 観測波形の後にゼロを付 け加える処理を事前に行うことが一般的であるが，本手 法ではさらに周波数の解像度を向上させるため, 加速度 波形に後続のゼロを大量につける必要がある.

このFFTのために作成された波形のイメージを図-2に 示す.「真の地震動」にゼロを加えた波形とステップ状 関数に後続のゼロをつけた波形（箱形関数）の足しあわ せになっている。ちなみに本検討内の計算では，FFTに

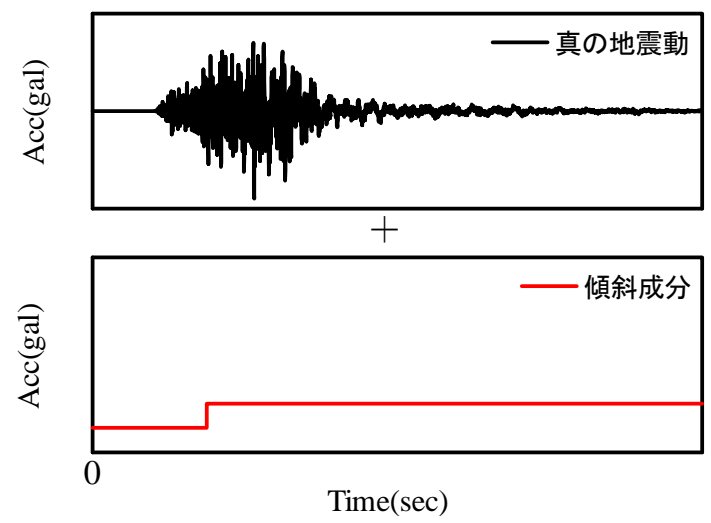

図-1 観測加速度波形の考え方

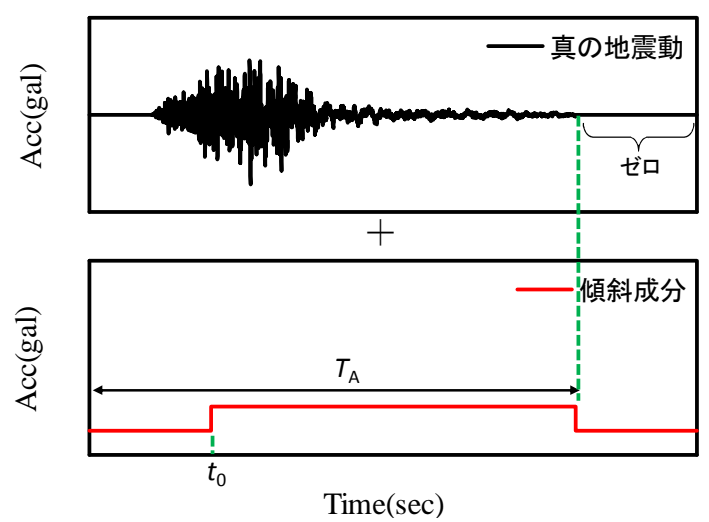

図-2 FTTを行うための波形

用いるデータ数が100万以上になる程度までゼロを付加 して計算を行った.

以上の処理により，FFTはこの波形の後ろに多数のゼ ロをつけた「地震動十箱形関数（ステップ状関数十ゼ ロ）」に対して行われることになり，得られる結果は 「地震動のフーリエスペクトル十箱形関数のフーリエス ペクトル」となる.このうち, 箱形関数 $s(t)$ のフーリエ スペクトル $S(\omega)$ は理論的に計算が可能であり, 次の式 で表される。

$$
S(\omega)=\frac{2 A \cdot \sin \left[\omega\left(\frac{1}{2}\left(T_{A}-t_{0}\right)\right)\right]}{\omega} \cdot e^{-i \omega_{0}}
$$

ここで, Aはステップ関数の振幅, $t_{0}$ はステップ関数の 開始時間を示す.

式(2)から，箱形関数は $\omega=0$ の時のフーリエ振幅 $S(\omega \rightarrow 0)_{\text {が }} A\left(T_{A}-t_{0}\right)$ となることが分かる. 加速度フー リエ振幅におていは， $\omega=0$ の振幅は，理論的にはゼロ であるので，観測記録のフーリエスペクトルにおける $\omega=0$ での振幅は, 傾斜成分による值 $\left(A\left(T_{A}-t_{0}\right)\right)$ で ある.また式(2)から $f=1 /\left(T_{A}-t_{0}\right)$ において $S(\omega)=0$ で ある.これにより，観測加速度波形のフーリエ振幅にお いて急激に振幅が落ちる最初の周期を $f=1 /\left(T_{A}-t_{0}\right)$ と 


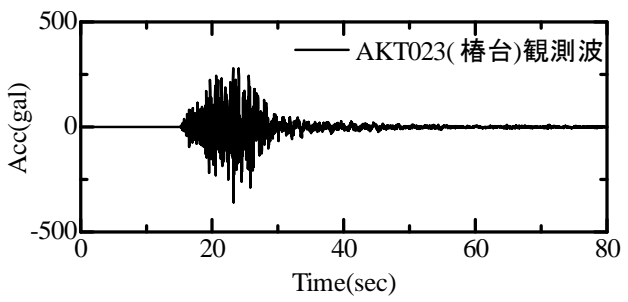

図-3 K-NET椿台（AKT023）観測波形

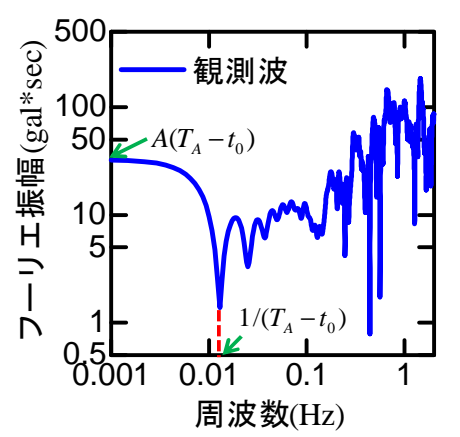

図-4＼cjkstart観測波フーリエスペクトル

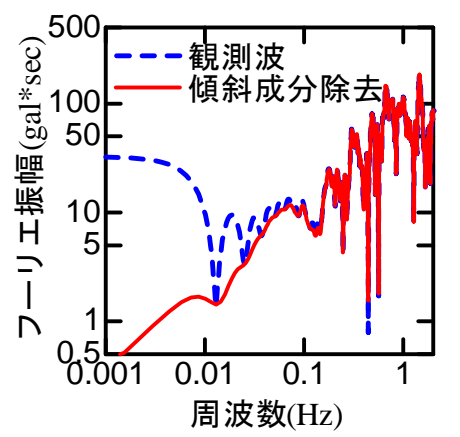

図-5 傾斜成分除去後のフーリエスペクトル

特定することができる．これらの条件から，ステップ状 関数の振幅 $A$, 開始時間 $t_{0}$ を特定することができる.

上述した観測記録の後続に大量のゼロを付加する処理 は, $f=1 /\left(T_{A}-t_{0}\right)$ の特定の精度を向上させる上で重要 な処理となる. 本来, 理論式としての箱形関数は, 連続 関数である. しかし, 数值処理においては, 有限個の数 值を扱わざるを得ない，この違いは，周波数領域の解像 度として表れる。つまり，理論式ではフーリエ振幅は式 (2)のように周波数領域で連続な関数として表現される のに対し，FFTで得られるフーリエ振幅はある解像度を 持った離散的な数列となる。ここで，FFTを行う前にゼ ロを十分に付加することは，箱形関数を理論式に近づけ ることを意味している。これは，周波数領域での解像度 の上昇として表れ，結果として，周期を特定する際の精 度が向上することになる。

なお古川らも，力学的な意味づけやFFTを行う波形の 解釈については考察していないものの, 計算手法につい ては類似の提案を行なっている ${ }^{4}$.

上記，ステップ関数の特定について，1ケースの例を
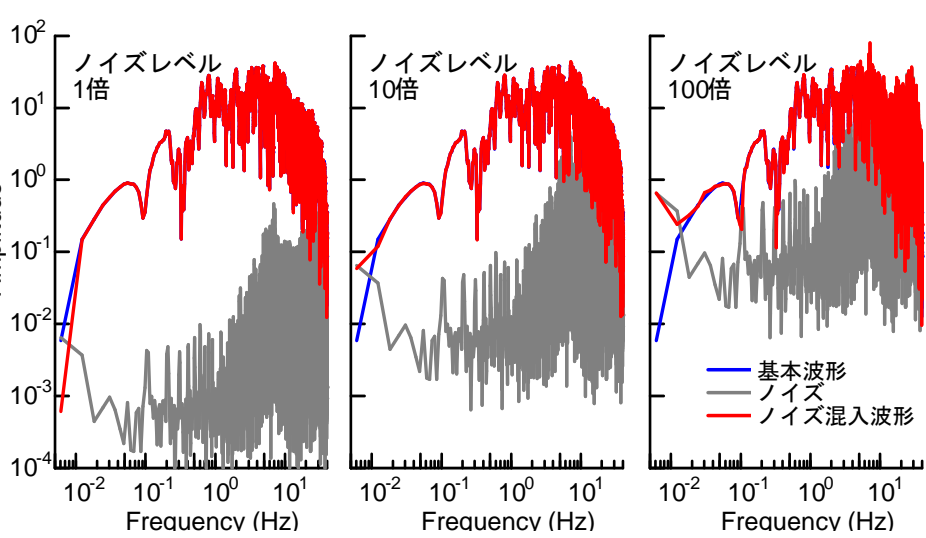

図-6 ノイズを混入した波形のフーリエスペクトル

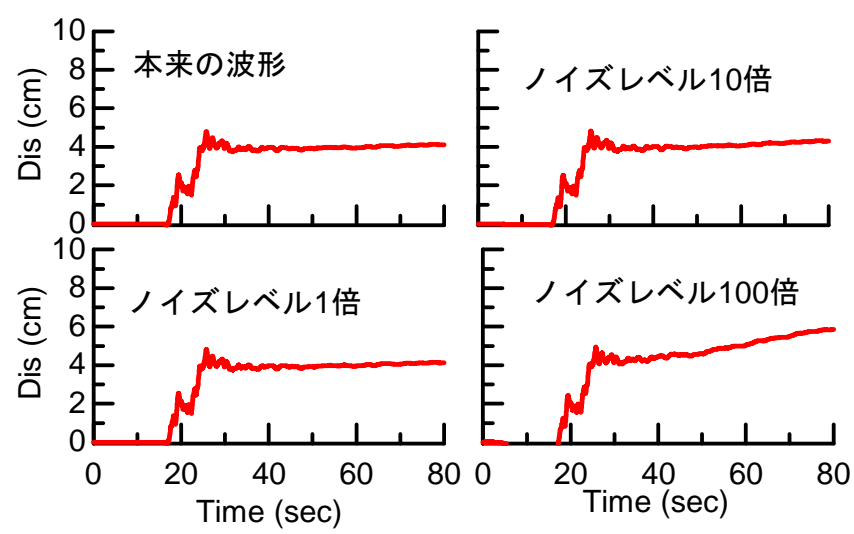

図-7 ノイズ混入加速度から求めた変位波形

示寸．図-3は岩手・宮城内陸地震（2008）において，KNETの観測点AKT023（椿台）で得られた観測加速度波 形（EW方向）である.これのフーリエスペクトルは， 図-4のようになる．これにより特定されたステップ関数 を観測記録から引き算することで，傾斜成分を除去した 波形が得られる. 傾斜成分を除去したフーリエスペクト ルは図-5のようになる．地震動の長周期成分の振幅が小 さいという特徵が表れたフーリエスペクトルが得られて いる.

\section{(2) 観測ノイズ}

文献4)においても指摘されているが，(1)の手法によっ てもトレンド成分が残るケースが多く存在する．原因と しては，上記で波形のトレンド成分のもう一つの要因と して指摘した観測ノイズの影響が考えられる。また，厳 密にはノイズではないが，地震計台の傾斜運動が仮定よ り複雑であることも原因であると推測される.

ここで提案する手法においては，物理的なトレンド成 分の特定を前節の傾斜成分までとし，残るトレンド成分 
についてはノイズとの分離が困難であるため, 周波数領 域の振幅をカットするようにした.

そこで，トレンド成分を除去するための最低限のフ イルタの設定方法について考察を行う。ここでは, 傾斜 成分などを含まず，永久変位を伴う基本加速度波形を例 題に取り上げる.この基本波形にノイズを人工的に付加 する.ノイズのレベルは1倍，10倍，100倍とした。 それ ぞれのフーリエスペクトルを図-6に示す。また，ノイズ を加えた加速度波形の時刻歴での積分により得られる変 位波形を図一7に示す。

ノイズレベルが100倍のケースにおいて，ノイズに起 因したトレンドが生じているが，この時のフーリエスペ クトルは，低振動数側で「くの字」に屈曲しているのが 分かる. スペクトルが折れている点より低振動数側では, ノイズレベルが真の信号より大きいことを意味する.よ って，スペクトルが屈曲する場合には，屈曲する振動数 を遮断振動数とした高域通過フィルタが, トレンド成分 を除去するための最低限のフィルタであると言える.

\section{（3）数値処理による波形の歪み}

前節で指摘したように，高域通過フィルタを用いる場 合は, 数值処理 (FFT/IFFT・フィルタ処理) そのものが トレンド発生の要因となり得る。ここでは, トレンド発 生の要因となるFFT/IFFTとフィルタ処理について, トレ ンドの発生をできるだけ抑える手法の提案を行う.

なお，ここで示寸手法は，著者の一人が文献5)で行な っている定式化を元に示すが，理論としては同等のもの が林らにより提案されている゙ . 数值処理上のコアとな る技術であるため説明を記載するが，本節で示すステッ プは，高域通過フィルタを用いる場合におけるサブステ ップとしての位置づけであることをあらかじめ記してお $<$.

\section{a) フーリエ変換によるトレンド成分の発生}

地震波のように因果律を満たす時間関数 $y_{m}$ は, 図-8 のように奇関数 $y_{m}^{o}$ と偶関数 $y_{m}^{e}$ の和で表され, さらに それぞれの関数は, 時間制限関数と超関数に分解が可能 である.このうち, 奇関数 $y_{m}^{o}$ には図に示寸ようにステ ップ状関数が含まれているが，これに対してフーリエ変 換をすると，点線のように直線のトレンドを仮定したフ ーリエスペクトルが得られる．これは，フーリエ変換が 周期関数を前提とする操作であることが原因である.

たとえば，図-9に示すように，ステップ状関数に似た 周期性のない波形を例にFFTを行い, 得られたフーリエ スペクトルに対してIFFTの処理を行ってみると, 図-10 のようになり, 元の波形が復元されない.

このことは，フーリエスペクトルにおいて振幅をカッ トするために, FFT/IFFTの処理を行うだけで，トレンド

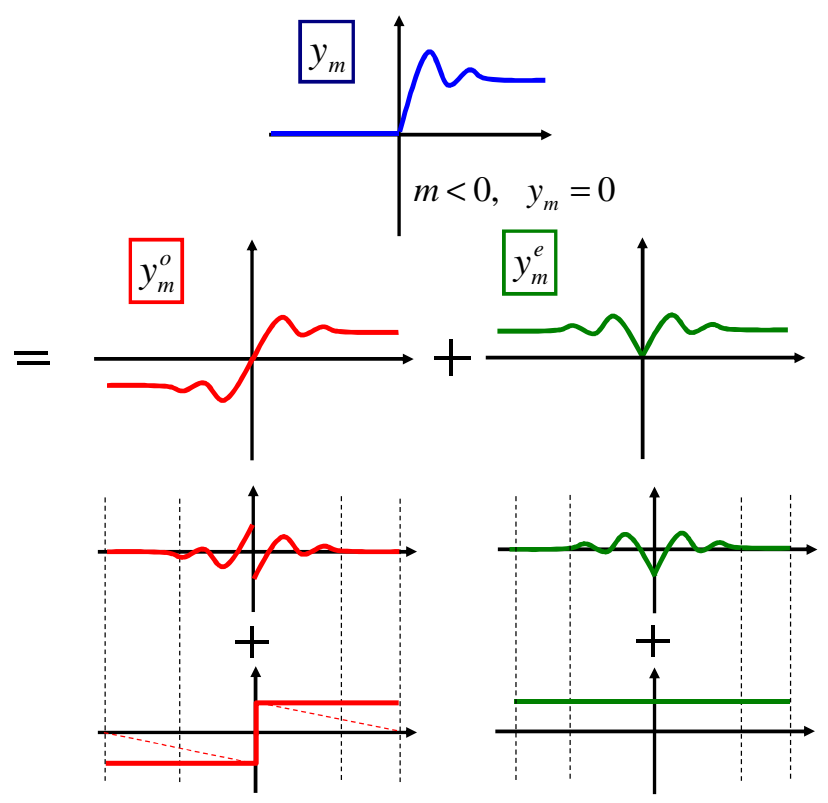

図-8 因果律を満たす時間関数の分解

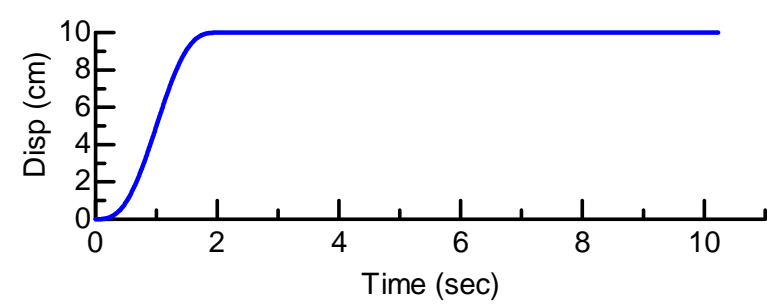

図-9 周期性のない波形

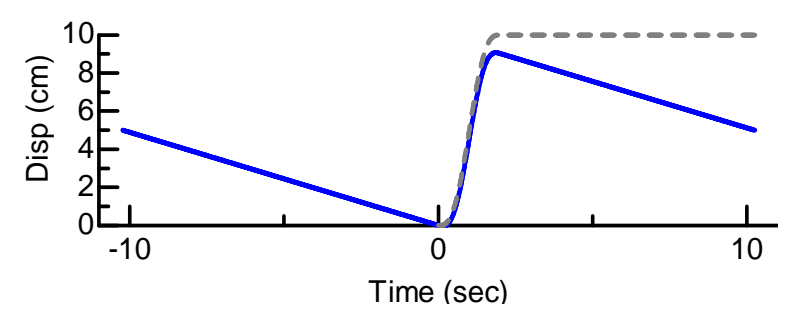

図-10 周期性のない波形に対して FFT/IFFT 処理を 行った結果得られる波形

が発生してしまうことを意味する.

\section{b) 周波数軸上での振幅のカットによるトレンド成分の 発生}

前項で説明した奇関数 $y_{m}^{o}$ と偶関数 $y_{m}^{e}$ は, それぞれ, 時間関数 $y_{m}$ のフーリエ変換の虚数部と実数部と, フー リエ変換・逆変換の関係にあることが著者の一人により 示されている5 . また, この虚数部と実数部は, 因果律 を満たすことを条件に式展開を行うと, 次の式により関 係付けられる。

$$
\begin{gathered}
\mathfrak{I}\left(C_{l}\right)=\sum_{k=-N / 2+1}^{N / 2} \beta_{l k} \cdot \mathfrak{R}\left(C_{k}\right) \\
\beta_{l k}=-\frac{2}{N} \sum_{m=1}^{N / 2-1} \cos \left(\frac{2 \pi k m}{N}\right) \sin \left(\frac{2 \pi l m}{N}\right)
\end{gathered}
$$




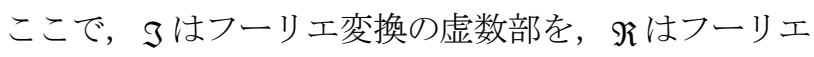
変換の実数部をそれぞれ表している.

周波数軸上で振幅をカット寸ること, つまり，ある周 波数領域の実数部と虚数部を一律ゼロとする処理は, 虚 数部および実数部に式(3)の関係を満たさない変化を与 えることを意味する．よって，この操作により因果律が 崩れるため，地震波形にトレンド成分が発生してしまう 要因となる.

また，低振動数領域においては，実数部より虚数部の 成分が大きくなることが一般に知られている．これによ り，フィルタ処理により低振動数成分をカットすると， 実数部より虚数部への影響が大きい. このため, フィル タ処理によるトレンド成分の要因としては, 虚数部の振 幅をカットする影響が大きく表れると考えられる。これ については，林らも同様の指摘をしているの．

\section{c) 因果律を拘束条件とした周波数軸上の積分}

ここでは，上記を踏まえ，加速度波形から変位波形を 計算する際に，ノイズが混入した長周期成分を落としつ つ, 上記の数值処理上のトレンド成分を避ける手法とし て, 次の手法を提案する.

(1)加速度波形のフーリエ変換を行う。

(2)実数部について，周波数軸上でフィルタをかける. そ の際, フーリエスペクトル上の低振動数側に表れる屈曲 点を遮断振動数としたハイパスフィルタを用いる.

(3) $1 /(i \omega)^{2}$ を乗じて変位波形のフーリエ変換 $D(\omega)$ を得る (ここでは, この操作を周波数領域での積分と名付け た）.

(4)実数部 $\mathfrak{R}[D(\omega)]$ から, 式(3)により虚数部 $\mathfrak{S}[D(\omega)]$ を復 元する.

(5)フーリエ逆変換により変位波形を計算する.

ここで，周波数軸上の処理の際に実数部のみを用いるの は, 虚数部を数值処理に含めると図-8に示寸奇関数 $y_{m}^{o}$ での数值処理が含まれることになり，上述のFFT/IFFTに よるトレンド成分が発生してしまうためである。また， 同じく前項で述べたが，低振動数領域では虚数部の振幅 が大きいため, 虚数部に対するフィルタ処理を行わない ことは，地震波形そのものに対する変化を抑える効果も あると考えられる。

ここに示した一連の手法を用いることで，フーリエ変 換およびフィルタ操作によるトレンド成分の発生を抑え た数值積分を行うことが可能である.

\section{3. 変位波形の計算手法の提案}

前章までをまとめる形になるが，本論文では，加速度 波形から変位波形を求める手法として, 以下の手法を提

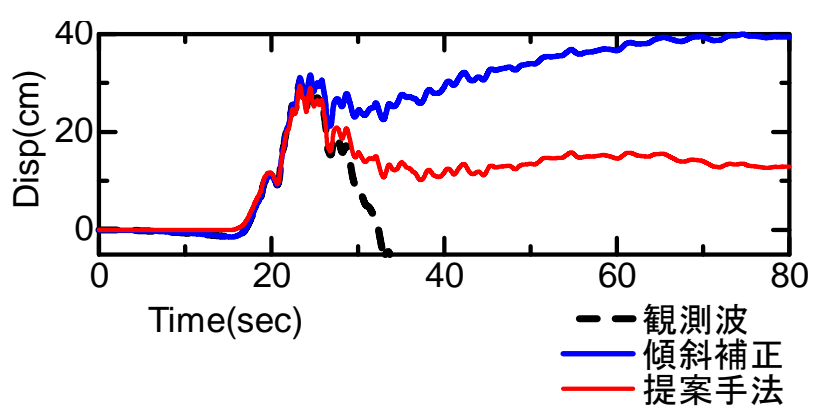

図-11 波形处理の例（K-NET椿台（AKT023） EW）
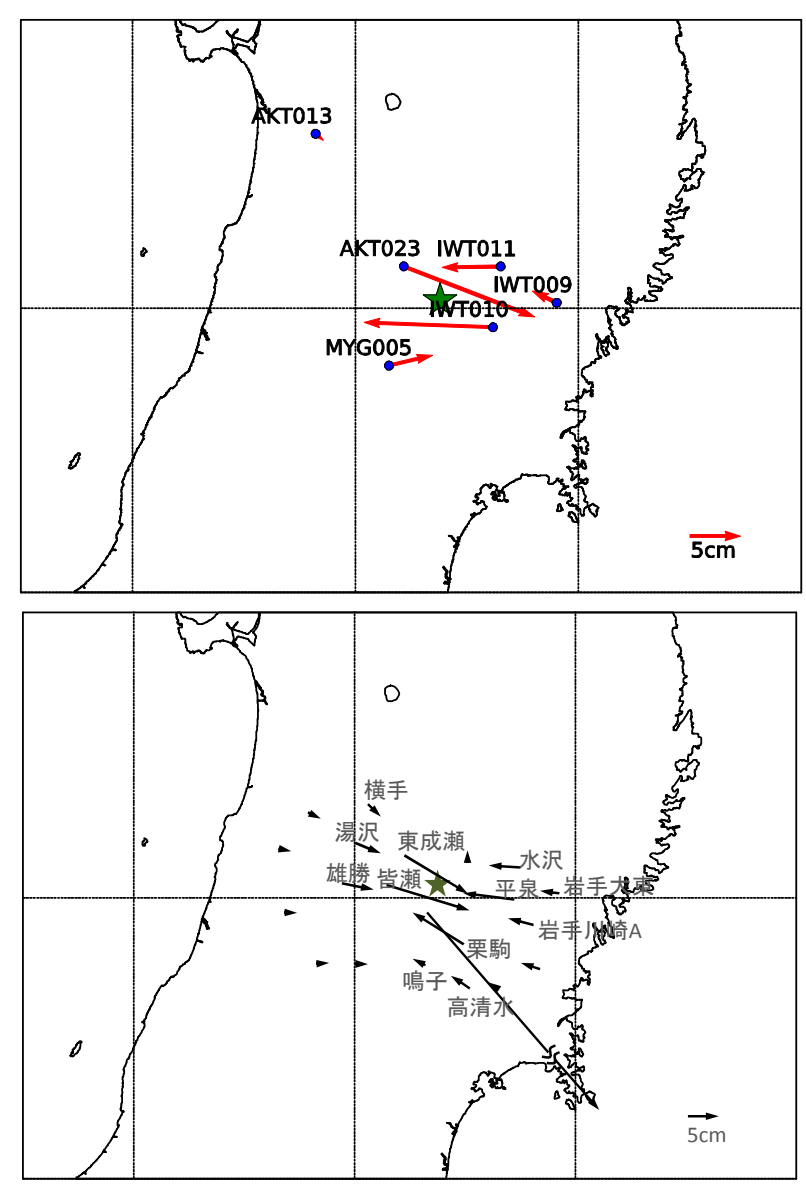

図-12 残留変位のプロット

(上 : 提案手法による水平変位分布)

(下 : GPS 観測による水平変位分布)

案する.

STEP1 : センサの傾斜成分の除去

センサの傾斜によるステップ状関数を2.(1)に示した手 法で特定し, 時間軸上の加速度波形から引き算し, 取り 除<.

STEP2 : 高域通過フィルタの適用

STEP1で得られた波形の積分を行い，変位波形を計算 すると，センサのノイズの影響によりトレンド成分が除 去できていない場合がある. その場合には，振動数領 域で振幅にフィルタをかける.この際，2.(2)に示すよう 
に, 遮断振動数はフーリエスペクトルの屈曲点とする. STEP3 : 周波数領域での加速度波形の積分

上記でフィルタをかけたフーリエスペクトルに対して, 2.(3)に示した周波数領域での積分を行う。この際, 因果 律を拘束条件とし，実数部のみを用いて積分を行うこと で, FFT/IFFTや上記フィルタ処理におけるトレンド成分 の発生を最小限に抑えることができる.

次章において, 本手法を岩手・宮城内陸地震（2008） に適用した例を示すが，本論文内で取り扱った波形にお いては，処理を行った全波形において，トレンド成分を 除去し, 残留変位が確認できる状態となっている.

\section{4. 岩手 $\cdot$ 宮城内陸地震への適用}

本章では，提案手法を岩手・宮城内陸地震（2008）の K-NET観測記録に適用する. 本地震は，南北に走る断層 が逆断層の挙動を示しており，断層を境界に東西で地款 変動が逆方向（断層に向かう方向にそれぞれ変位する） となっていることが一つの特徴となっている.

\section{(1) 波形処理の例}

ここでは，上でも扱ったK-NET椿台（AKT023）のEW 方向における波形処理を示寸. 処理結果は図-11に示し た.ここでは, 観測加速度波形から単純な積分により得 られる変位波形も重ねて示しているが，負の方向に大き なトレンド成分を持ち，波形がグラフのプロット範囲に 収まっていない結果となっている.

STEP1にあたる傾斜成分の特定・除去を行い，提案手 法のSTEP2より時間軸上での積分を行った結果は, 傾斜 補正のみ行った結果の波形として, 図-11に「傾斜補 正」として示している.上述の観測加速度記録の単純な 積分結果に比べて, トレンド成分が抑えられているが, 地震動が落ち着いてからも振幅が徐々に増加するトレン ドが発生している，そこで，本波形については，手法に 従いSTEP3を実施した。 その際，フーリエ振幅の実数部 は0.026Hz以下をカットする高域通過フィルタを施した これにより，トレンド成分が除去できた変位波形を得る ことができた（図-11提案手法）。また，今回検討対象 とした地震加速度観測記録においては，全て傾斜成分を 除去後に, 長周期成分を除去寸る必要があった.

\section{(2) 波形処理の活用の例}

地款変動を計算する手法としての活用例を示す.

本地震の観測点を数点選び，上記手法で得られる残留 変位を地図上にプロットした（図-12上）。参考として, 国土地理院で公開されているGPS連続観測網の観測結果
をトレースしたものを示す（図-12下）》．

それぞれの地震系が設置された位置・深さでの正確な 変位が計測されている訳ではないので, 波形処理の精度 については議論が難しいが，断層を挟んで水平変位が逆 になっている点や変位量など，GPS観測による地款変動 とも概ね整合がとれており，提案した手法が変位波形を 計算する手法として十分実用的であることが分かる.

\section{5. まとめ}

加速度記録から変位記録を計算する際には，長周期成 分がセンサの傾きや観測ノイズなどの影響を受けること により，変位波形にトレンド成分が生じる，正確な変位 を推定するため，まず，地震記録から傾斜成分を分離し， 本来必要な並進成分のみを抽出するための手法を考えた. この手法により, 周波数領域でカットする領域が格段に 狭くなることが確認されている.

さらに，本論文では，フィルタ操作を行う上で，フー リエ変換や, 周波数領域での振幅のカットなどといった 数值的な操作が, 波形を歪ませないように, 因果律を拘 束条件として，波形を周波数領域で積分する手法を合わ せて用いている.

以上の手法により, 長周期成分におけるノイズを除去 し，かつ，地震波形が本来有している長周期成分の情報 を極力失わない手法が提案できた.

最後に，本手法を実際の観測記録に対して適用し，手 法の活用性の検証を行った.

謝辞 : 本研究では, 防災科学技術研究所の強震ネットワ ークK-NETの記録を使わせて頂いた．感謝の意を記す。

\section{参考文献}

1) 太田良巳，アイダン・オメル : 加速度から変位を求める積分 手法と実地震記録への適用，「海一自然と文化」東海大学 紀要海洋学部第 5 巻第 2 号,pp. 1-12,2007.

2) Vladimir M. Graizer. Effects of tilt on strong motion data processing, Soil Dynamics and Earthquake Engineering, 25, pp.197-204, 2005.

3) Vladimir M. Graizer: Record processing considerations for the effects of tilting and transients, Proc. of COSMOS Strong Motion Workshop, Richmond, CA., 2004.

4) 古川陽, 井上修作, 大町達夫 : 震源近傍における永久変位を 含む強震記録の積分補正手法の検証, 土木学会第65回年次 講演会, pp.651-652, 2010.

5) 佐藤忠信, 室野剛隆 : 位相情報を利用した非定常地震動のシ ミュレーション法，土木学会論文集 第1-66号, pp.159-168, 
2004.

6) 林康裕，勝倉裕，渡辺孝英，片岡俊一，横田治彦，田中貞 二 : デジタル強震計の加速度記録を積分して得られる変位 の信頼性について, 日本建築学会構造系論文報告集第419号, pp.57-66, 1991 .
7) 国土地理院 : 平成20年 (2008年) 岩手・宮城内陸地震に伴う 地款変動（第2報）,2008.

\section{CALCULATION TECHNIQUE TO ACQUIRE DISPLACEMENT FROM SEISMIC ACCELERATION RECORDS}

\section{Hiroki MOTOYAMA Yoshitaka MURONO}

Computing displacement from measured acceleration is important for understanding the characteristics of an earthquake. However, to obtain such displacement with a good accuracy is difficult. It is partly because the low-frequency component dominating the behavior of the displacement is often affected by the sensor's tilt and the measurement error. In this paper, a new methodology to get the acceleration without those undesirable effects is proposed. In addition, the integration method in frequency domain for computing displacement from the obtained acceleration is proposed, considering causality as a constraint to avoid the numerical error. Using these techniques, the estimation of residual displacement of the 2008 Iwate-Miyagi Nairiku Earthquake is attempted. 